\title{
Organic black tiger shrimp farming system (iso 65 ifoam): strategy through open spirit reap back to
} \section{nature}

\begin{abstract}
The strategy is very logical considering cultured shrimp is for export, not to meet the domestic market demand. The object studied is the traditional shrimp farmers and organic shrimp farmers. The purpose of research is to find a strategy of foreign exchange earned through the implementation of organic shrimp farming systems (ISO 65 IFOAM). The study used a descriptive approach. To find a strategy using SWOT analysis of foreign exchange earned by weighting the Balanced Score Card. While the effects of the implementation of shrimp farming organic systems analysis with Snow Ball Effect Matrix Balanced Score Card. The results showed that through the implementation strategy organic shrimp farming systems following priority actions are: strengthening the bargaining power in the international market through the supply of organic shrimp exports were stable throughout the year, improving the quality of the supply of organic shrimp.
\end{abstract}

Keywords: Organic, Black tiger, Shrimp farming system, Strategy, Nature
Volume 4 Issue I - 2016

Angky Soedrijanto, Titis Istiqamah

Lamongan Islamic University, Indonesia

Correspondence: Angky Soedrijanto, Lamongan Islamic University, Lamongan, Merdeka University, Pasuruan, East-Java, Indonesia,Tel +628I25230057I, Email agustitantu@yhoo.com

Received: October 24, 2015 | Published: February 15, 2016
Abbreviations: MMAF, Ministry of Maritime Affairs and Fisheries of Indonesia; GBP, Good Breeding Practices; SOP, Standard Operation Procedures

\section{Introduction}

The Ministry of Maritime Affairs and Fisheries of Indonesia (MMAF) requires seed until 43.22 million and 2.97 million stem tail shrimp exports in order to meet the target and reach the stage of self-sufficiency. Target national shrimp production during the period 2010-2014 amounted to 699000 tonnes in 2014, an increase of 74.75 percent. ${ }^{1,2}$ Barriers to developing broodstock shrimp is the declining quality. The resulting seed the slower growth and higher mortality when cultivated. The results showed that the problem is due to the occurrence of 'inbreeding', ${ }^{3-5}$ There is no regulation of the Government Good Breeding Practices (GBP) or Standard Operation Procedures (SOP) of shrimp breeding that are technically capable of guaranteeing seeding procedure free of antibiotics. In other words, the perpetrators of seeding are: fishermen of broodstock and breeders in hatchery require a valid SOP or able to guarantee high productivity and healthy seed. ${ }^{6}$ Procedures should be implemented in different places and times, and easily understood by business people seeding. Observations in Tuban, Situbondo and Banyuwangi indicates that: since 2004-2005 then gradually hatcheries have started doing the change of seeding. These changes are starting to leave the use of antibiotics and other chemicals; promote the use of probiotics as well as vitamins and other nutritional supplements for both the broodstock and seed shrimp.

Technicians at the hatchery there are still some who liked the use of antibiotics. Antibiotics that have been harmful active ingredients prohibited by the Government, and no longer sold by companies engaged in the marketing of fishery production facilities. For that, each year ASPAKINDO (Indonesia Aquaculture Facility Association) publishes an index that contains fish medicine drug outstanding fish and shrimp, ${ }^{7,8}$ which are permitted and prohibited the circulation; following the rules of government agencies. Strong support from the business line of the main of Indonesia shrimp business in East Java such as: aquaculture entrepreneurs; largely determine the development of the breeding technical, methodological and encourage a change of mindset most businesspeople seeding.

Changes pembenih thought to produce seed naturally it was not followed by the same thinking among farmers shrimp in ponds. The phenomenon of high-density stocking of fry in the ponds, the pursuit of the national production target as well as the great economic benefits is conflicting policies. The government still seems to think chasing a target of foreign exchange for the country through the approach of quantity rather than quality. Meaning: great production is believed to generate a substantial income. Strategy should be developed is an attempt to obtain foreign exchange from high quality shrimp; among others, by the way berbudidaya shrimp organic systems. Implemented the strategy is very logical considering shrimp farming is for export, not to meet the domestic market demand.

\section{Purpose}

Finding the foreign exchange earned through implementation strategy shrimp farming organic systems (ISO 65 IFOAM).

\section{Methodology}

The study used a descriptive approach. Location studied is the business of hatchery and shrimp farming in East Java. When the study began in January $2011 \mathrm{~s} / \mathrm{d}$ in December 2012 for 2 years. The method used is a terrestrial survey by visiting hatcheries and aquaculture shrimp randomly. Tools to obtain data was a questionnaire. The substance under study obtained from direct interviews and questionnaires openly by the respondent. Respondents were pembenih and shrimp farmers have experienced, selected based on the information and observations on the credibility of research respondents.

Results of the interviews were analyzed using the SWOT matrix by weighting the Balanced Score Card to find strategies to reap foreign exchange. While the effects of the implementation of shrimp farming organic systems (ISO 65 IFOAM) was analyzed by matrix Snow Ball Effect Balanced Score Card. 


\section{Results and discussion}

The results of the appreciation of the farmers in order to implement the shrimp farming organic systems had shown a very positive response. The main reason put forward by the respondent is a strong desire to maintain the sustainability of the carrying capacity of natural resources in hatcheries and shrimp farms theirs. However, a strong desire is still feared to encounter many obstacles. The most severe constraint is to build solidarity among pembenih perception in hatcheries and growers. Respondents believe that in addition to shrimp farming with organic systems will provide business continuity in the long run, the economic benefits will also bring benefits not less. ${ }^{9,10}$

Based on the calculation of the farmers business, results of organic shrimp will certainly bigger size and quality that will bring additional minimum price equivalent to 1 USD per kilogram head on. In addition, the price of shrimp in the world shrimp market average is higher than the price of Vannamei shrimp. So if the productivity per hectare farmed shrimp with traditional systems are able to produce at least 400 kilograms per cycle: by cultivating organic systems even though productivity is the same but the size of the harvested shrimp tend to be larger so that the value of the money earned is greater.

Black tiger shrimp is one of mainstay export fisheries should pay attention to quality and food safety aspects. ${ }^{1}$ Benefits of the implementation of organic farming systems is the lack of production costs, as well as antibiotic substances obtained from natural probiotics around the pond..$^{3,5,9-13}$ Therefore, it is important for farmers to know how applicable the manufacture of antibiotics and probiotics from mangroves and mangrove plants instead.From the results of the interview, the foreign exchange earned through implementation strategy shrimp farming organic systems can be formulated as follows; SWOT analysis Balanced Score Card shows that there are three strategies can be pursued with the following priorities:

A. Strengthen their bargaining position in the international market through the supply of shrimp shrimp exports were stable throughout the year; scores 180 .

B. Improving the quality of the supply of organic shrimp, shrimp farming organic means must be developed to generate good quality shrimp and highly competitive in the international market; scores 100 .

C. Improving the quality of parent shrimp through the application of marine sanitation program Indonesia; scores 10 .

Based on the priority actions SWOT analysis results are then translated into programs and actions to be taken by the Government holistically with all parties concerned. Programs and actions taken must be based on a common vision and mission of all stakeholders to improve the environmental quality of the waters of Indonesia to be able to produce high quality organic shrimp, while maintaining natural resources and sustainability (Table 1).

Being programs and actions to be performed on the matrix effects appear shrimp aquaculture implementation organic system implementation is measured by using the priority ranking matrix Snow Ball Effect Balanced Score Card (Table 2).

Table I SWOT-BSC Analysis Strategy Through Open Spirit Reap Back to Nature

\begin{tabular}{|c|c|c|c|c|c|c|c|}
\hline & & Strength & & Weakness & & & \\
\hline & & $\begin{array}{l}\text { The price is more expensive than } \\
\text { black tiger shrimp vannamei shrimp }\end{array}$ & 90 & $\begin{array}{l}\text { The price of shrimp is determined } \\
\text { by export destination countries }\end{array}$ & -30 & & \\
\hline Internal Factor & & $\begin{array}{l}\text { Shrimp Tiger shrimp is native to } \\
\text { Indonesia }\end{array}$ & 90 & $\begin{array}{l}\text { The quality of the natural parent } \\
\text { shrimp tend to be low }\end{array}$ & -80 & Compilation & \\
\hline & & $\begin{array}{l}\text { The quality is higher than the black } \\
\text { tiger shrimp vannamei shrimp }\end{array}$ & 90 & $\begin{array}{l}\text { Post-harvest handling can be } \\
\text { improved }\end{array}$ & -50 & & \\
\hline Opportunity & & Strategy S-O & & Strategy W-O & & Strategy SWO & \\
\hline $\begin{array}{l}\text { Price fluctuations } \\
\text { are more stable } \\
\text { shrimp }\end{array}$ & 70 & $\begin{array}{l}\text { To strengthen the bargaining } \\
\text { position of international market } \\
\text { prices }\end{array}$ & 160 & $\begin{array}{l}\text { To strengthen the bargaining } \\
\text { position of international market } \\
\text { prices }\end{array}$ & 40 & $\begin{array}{l}\text { Strengthen bargaining } \\
\text { shrimp prices in the } \\
\text { international market }\end{array}$ & 200 \\
\hline $\begin{array}{l}\text { Parent comes from } \\
\text { local waters and } \\
\text { easy to obtain }\end{array}$ & 80 & $\begin{array}{l}\text { Increase parent handling a good } \\
\text { technical }\end{array}$ & 170 & $\begin{array}{l}\text { Improving the quality of local } \\
\text { shrimp broodstock }\end{array}$ & 0 & $\begin{array}{l}\text { Improving the quality } \\
\text { of local shrimp } \\
\text { broodstock }\end{array}$ & 170 \\
\hline $\begin{array}{l}\text { Total Score } \\
\text { Opportunity }\end{array}$ & 250 & Score Strategy S-O & 520 & Score Strategy W-O & 90 & & \\
\hline Threath & & Strategy S-T & & Strategy W-T & & Strategy SWT & \\
\hline $\begin{array}{l}\text { Prices can be } \\
\text { influenced another } \\
\text { shrimp supply }\end{array}$ & -40 & $\begin{array}{l}\text { Strengthen the export supply that } \\
\text { is always available }\end{array}$ & 50 & $\begin{array}{l}\text { Strengthen the export supply that } \\
\text { is always available }\end{array}$ & -70 & $\begin{array}{l}\text { Strengthen the } \\
\text { export supply that is } \\
\text { always available }\end{array}$ & -20 \\
\hline $\begin{array}{l}\text { Indication of any } \\
\text { outbreak of the } \\
\text { virus in the waters } \\
\text { of Indonesia }\end{array}$ & -80 & $\begin{array}{l}\text { Develop a marine sanitation } \\
\text { program Indonesia }\end{array}$ & 0 & $\begin{array}{l}\text { Develop a marine sanitation } \\
\text { program Indonesia }\end{array}$ & -160 & $\begin{array}{l}\text { Develop a water } \\
\text { sanitation program } \\
\text { Indonesia }\end{array}$ & -160 \\
\hline $\begin{array}{l}\text { Low productivity } \\
\text { due to illness and } \\
\text { bacterial infections }\end{array}$ & -90 & $\begin{array}{l}\text { Improving the quality of the } \\
\text { application of organic }\end{array}$ & 0 & $\begin{array}{l}\text { Designing systems minimize the } \\
\text { risk of partial harvesting }\end{array}$ & -140 & $\begin{array}{l}\text { Apply organic } \\
\text { cultivation and } \\
\text { harvesting systems of } \\
\text { partial }\end{array}$ & -140 \\
\hline
\end{tabular}


Table Continued..

Total Score Threath -220

\section{Score Strategy S-T Strategy SOT}

To strengthen the bargaining position through export supply
50

Develop a program of sanitation and handling a good parent
170

Develop a program of sanitation and handling a good parent

\section{Score Strategy W-T Strategy WOT}

To strengthen the bargaining position through export supply
$-380$

\section{Strategy SWOT}

To strengthen the bargaining position through export supply

Improving the quality of the broodstock through the sanitary 10 water

Improving the quality of the supply of $\quad 100$ organic shrimp

Improving the quality of the supply 190

Improving the quality of the supply of organic shrimp of organic shrimp

Table 2 Snow Ball Effect Matrix Balanced Score Card Implementation System Organic Tiger Shrimp Cultivation

\begin{tabular}{|c|c|c|c|c|c|c|}
\hline $\begin{array}{l}\text { Factor SWOT } \\
\text { strategy }\end{array}$ & score & Effect I programs & score & Effect 2 action & $\begin{array}{l}\text { Correction } \\
\text { score }\end{array}$ & $\begin{array}{l}\text { Ranked of } \\
\text { priority action }\end{array}$ \\
\hline \multirow{4}{*}{$\begin{array}{l}\text { To strengthen } \\
\text { the bargaining } \\
\text { position through } \\
\text { export supply }\end{array}$} & \multirow{4}{*}{180} & $\begin{array}{l}\text { Facilitate the breeder and supply of } \\
\text { shrimp aquaculture on the importance } \\
\text { of organic }\end{array}$ & 40 & $\begin{array}{l}\text { FGD among professional } \\
\text { organizations to create a unified } \\
\text { vision, mission and technical follow } \\
\text { the steps in the production of } \\
\text { organic shrimp }\end{array}$ & 48 & 4 \\
\hline & & $\begin{array}{l}\text { Facilitation of export promotion for } \\
\text { organic shrimp }\end{array}$ & 30 & $\begin{array}{l}\text { Increase promotion of organic } \\
\text { shrimp meal }\end{array}$ & 28 & 6 \\
\hline & & $\begin{array}{l}\text { Incentives for developers of shrimp } \\
\text { farming organic systems }\end{array}$ & 60 & $\begin{array}{l}\text { Provision of subsidies in the form } \\
\text { of additional selling price of organic } \\
\text { shrimp to cold storage }\end{array}$ & 62 & I \\
\hline & & $\begin{array}{l}\text { De-regulation of the organic shrimp } \\
\text { exports as a strategic product }\end{array}$ & 50 & $\begin{array}{l}\text { Provide easy document and export } \\
\text { procedures }\end{array}$ & 42 & 5 \\
\hline \multirow{2}{*}{$\begin{array}{l}\text { Improving the } \\
\text { quality of the } \\
\text { supply of organic } \\
\text { shrimp }\end{array}$} & \multirow[b]{2}{*}{100} & $\begin{array}{l}\text { Encourage hatchery seed organic } \\
\text { produce }\end{array}$ & 50 & $\begin{array}{l}\text { Providing subsidies seed sales price } \\
\text { of organic }\end{array}$ & 49 & 3 \\
\hline & & Strengthen the anti antibiotics & 50 & $\begin{array}{l}\text { Tightening up the circulation } \\
\text { of harmful active ingredients to } \\
\text { pharmacies and drug stores }\end{array}$ & 51 & 2 \\
\hline \multirow{2}{*}{$\begin{array}{l}\text { Improving the } \\
\text { quality of the } \\
\text { broodstock } \\
\text { through the } \\
\text { sanitary water }\end{array}$} & \multirow[b]{2}{*}{10} & $\begin{array}{l}\text { Strengthen legal action to discharge } \\
\text { waste into public waters }\end{array}$ & 5 & $\begin{array}{l}\text { Socialization to strengthen the } \\
\text { understanding of law enforcement }\end{array}$ & 2 & 8 \\
\hline & & $\begin{array}{l}\text { Strengthen oversight of waste disposal } \\
\text { into public waters }\end{array}$ & 5 & $\begin{array}{l}\text { Providing incentives for reporting } \\
\text { any malpractice waste disposal }\end{array}$ & 8 & 7 \\
\hline
\end{tabular}

Based on the analysis; then four priority ranking appropriate action to be taken within the framework of the implementation of shrimp farming organic systems ISO 65 (IFOAM) as a strategy for foreign exchange earned through the spirit of back to nature is:

a. Subsidies in the form of additional selling price of organic shrimp into cold storage; whereby unnecessary subsidies provided through the Government's budget but are automatically derived from the difference between the export price of organic shrimp is higher than the export price of shrimp is not organic. The price difference should be transformed by both the farmers and hatchery through the marketing chain running. ${ }^{6,7,11,15,16}$

b. Tightening up the circulation of harmful active ingredients to pharmacies and drugstores. ${ }^{1,8,12,17}$ This effort can only be done by the drug regulatory revitalize and chemicals and strict supervision in distribution.

c. Subsidizing prices to farmers selling organic seed. . $7,11,15,16$ The process of granting these subsidies will occur automatically as additional subsidies in the form of the sale price of organic shrimp to cold storage. d. FGD among professional organizations to create a unified vision, mission and technical follow the steps in the production of organic shrimp; an important activity that should be increased intensity of implementation through government facilitation ${ }^{16,17}$ stated that: vision, mission and action steps that synergistic interprofessional organization will encourage the spirit of back to nature by applying the shrimp farming organic systems which will ultimately be able to reap the expected foreign exchange together.

\section{Conclusion}

Strategies division raked through the implementation of shrimp farming organic systems ISO 65 (IFOAM) following priority actions are:

i. Strengthen their bargaining position in the international market through the supply of shrimp shrimp exports were stable throughout the year

ii. Improving the quality of the supply of organic shrimp, shrimp farming organic means must be developed to generate good quality shrimp and highly competitive in the international market 
iii. Improving the quality of broodstock shrimp through the application of marine sanitation program in Indonesia.

\section{Acknowledgments}

None.

\section{Conflicts of Interset}

None.

\section{References}

1. Official Control Traceability (OCT) Code. The Basic Supporting of Assuring Official Safety Control Program and Supplier Approval Program. East Java Fisheries Quality and Safety Assurance System. Laboratory Quality Testing Center of Fishery. Surabaya. 2010

2. Department of Marine Fisheries National Shrimp Production Runway Department of Marine Fisheries. Jakarta. 2008

3. Bachi R Improving Aquaculture Practices in Smallholder Shrimp Farming. Shrimp Training Manual. 2009

4. Khamnamtong B, Klinbunga S, Menasveta P (2005) Species Identification of Five Penaeid Shrimps Using PCR-RFLP and SSCP Analyses of 16S Ribosomal DNA. J Biochem Molecul Biol 38(4): 491-499.

5. Bengtsson J, Antshrom J, and Weibull AC The Effects of Organics Agriculture on Biodiversity and Abundance: a Meta Analysis. Journal Applied Ecology. 2005;42:261-269.

6. Scoot F Demand for Organic Food Growing Faster Than Domestic Supply. Chesapeake Bay Journal 6. 2006

7. Nirmala K, Yuniar E, Budiardi T Productivity and Basic Chemical Parameters Tiger Shrimp Pond Farming Penaeus monodon Fab. Aged 1 and 3 years. Indonesian Aquaculture Journal. 2005;4(1):5-11.
8. Vass M, Hruska K, Franek M Nitrofuran antibiotics: a review on the application, prohibition and residual analysis. Veterinarni Medicina. 2008;53(9):469-500.

9. Kosim Organic Tiger Shrimp Culture Project in Sidoarjo. Ali Ridho Group, Sidoarjo, Indonesian. 2003

10. Kosim HM, Elin Arlyni, Ady Sukma Traceability Application Handbook for Process Black Tiger Shrimp and Vannamei Shrimp. CV. Ali Ridho Fees Through Group Process in PT. Glimpses of the Eastern StarNapier, Sidoarjo. 2007

11. Lampkin NH Organic Farming in the European Union: Overview, Policies and Perspective. University of Wales, UK. 1999

12. Abu Hena MK, Sharifuzzaman SM, Hishamuddin O, et al. Pond Health Management of Black Tiger Shrimp Penaeusmonodon (Fabricius) Using Bacterial Products. Diseases in Asian Aquaculture. 1999;469-476.

13. Moran D Market Creation for Biodiversity: The Role of Organic Farming in the EU and US. Paris: Organisation for Economic Cooperation and Development. 1999

14. Nurdjana, Made L Featured Shrimp Fishery Exports. Voice Updates. Jakarta, Indonesia. 2008

15. Padel S Conversion to Organic Farming: A Typical Example of the Diffusion of an Innovation? European Society for Rural Sociology. 2001;41(1):41-61.

16. Paul J China's Organic Revolution. School of Geography \& Environmental Studies, University of Tasmania, Australia. Journal of Organics Systems. 2007;2(1):1-11.

17. Soedrijanto A Official Control Traceability Implementation in the Context of Performance Enhancement Tiger Shrimp Exports of Organic Systems in Sidoarjo: Case Studies CV. Ali Ridho. Thesis. Masters Program in Agribusiness Management-UPN Veteran East Java. Surabaya. 2009. 